\title{
HERBICIDE EFFICACY IN RELATION TO HERBICIDE RATE, SURFACTANT RATE AND SPRAY APPLICATION VOLUME
}

\author{
J.W. RAY, B. RICHARDSON, A.L. VANNER and G. COKER \\ Plantation Forest Protection, New Zealand Forest Research Institute Ltd., \\ Private Bag 3020, Rotorua, New Zealand
}

\begin{abstract}
In two experiments, a central composite response surface design was used to investigate the interactions between herbicide rate (glyphosate in Experiment 1 and metsulfuron in Experiment 2), surfactant rate, and spray application volume on tomato dry weight production. In both experiments, dry weight production was affected by herbicide, and surfactant rate but not spray application volume. Equations derived to predict the response of tomato dry weight production to rates of either, glyphosate or metsulfuron, and surfactant explained $89 \%$ and $75 \%$ of the observed variability respectively. The results suggest that spray application volumes may be decreased without reducing herbicidal efficacy, provided the rates of herbicide and surfactant are maintained constant.
\end{abstract}

Keywords: herbicide, surfactant, application volume, efficacy.

\section{INTRODUCTION}

Woody weeds, which severely reduce tree growth if allowed to develop unchecked, have proved difficult to control with herbicides. Balneaves et al. (1993) showed that although high rates of glyphosate failed to control gorse, adding an organosilicone surfactant to the spray mix dramatically increased efficacy. There was a highly significant interaction between surfactant rate and herbicide dosage; efficacy could be maintained at lower herbicide rates by increasing surfactant rate. Organosilicone surfactants have major effects on the uptake of agrochemicals by plant foliage (Stevens et al. 1991) and this topic has been extensively investigated and reviewed (Stevens 1993; Knoche 1994).

Ray et al. (1986) showed that aerial spray volumes could be reduced without reducing the efficacy of bracken control provided per hectare rates of herbicide and surfactant were held constant. Using lower aerial spray volumes is desirable because it increases aircraft productivity (Ray et al. 1991), reduces costs and makes better use of weather suitable for aerial application.

The present trial was undertaken to investigate the interaction of carrier volume and surfactant rate on the herbicide efficacy using tomatoes as an indicator plant.

\section{MATERIALS AND METHODS}

Tomato plants (Lycopersicum esculentum cv. Russian Red) were raised from seed, in a glasshouse, using individual $600 \mathrm{ml}$ square pots containing a standard potting mix. Two trials were undertaken, one using glyphosate (Roundup GI, $360 \mathrm{~g} /$ litre), and the other metsulfuron (Escort $600 \mathrm{~g} / \mathrm{kg}$ ). Three experimental factors were examined: total spray volume (litres/ha), herbicide rate $(\mathrm{kg} / \mathrm{ha})$, and organosilicone surfactant (Pulse) rate (litres/ha). The range of levels for each factor were selected according to a centralised composite response surface design (Cochran and Cox 1968) giving a total of 15 treatments (Table 1). Treatments were replicated 10 times, except for treatment 6 , which, as is usual with a centralised composite design, was replicated 60 times to ensure that the precision of prediction was the same at the centre as for the other experimental points. The same application volumes and surfactant rates were used for both herbicides. The mid point for the range of herbicide rates approximates to the $\mathrm{ED}_{50}$ at the recommended surfactant rate. 
Plants were sprayed with freshly prepared solutions using a Forest Research built track sprayer fitted with single nozzle (TeeJet 8001E, Spraying Systems Ltd), located $500 \mathrm{~mm}$ above the average plant height. Changes to the application volume were achieved by changing belt speed.

Sprayed plants were returned to the glasshouse immediately after treatment. Above ground dry weight was determined for each plant, 21 or 13 days after spraying with glyphosate or metsulfuron respectively.

Data analysis was undertaken using SAS software (SAS Institute Inc. 1988). Multiple linear regression was used to investigate relationships between the three experimental variables and tomato dry weight. A logarithmic transformation of tomato dry weight was required to linearise the data. All interactions between independent variables and quadratic terms were included in the initial model, and a backwards selection procedure was used to determine significant variables for the final model. Following selection and fitting of the models, residuals were plotted and examined.

\section{RESULTS AND DISCUSSION}

The results are given in Table 1 . The data point with zero herbicide applied was omitted from the analysis as the residual values for this treatment was clearly biased for both herbicides. The resulting models were highly significant, $\mathrm{P}=0.0001$ and $\mathrm{P}=$ 0.0005 for the glyphosate and metsulfuron experiments respectively. No significant interaction was detected between application volume (litres/hectare) and surfactant volume (litres/hectare). The best fitting model for the glyphosate experiment included terms for glyphosate rate $(\mathrm{P}=0.0001)$, surfactant rate $(\mathrm{P}=0.0002)$, and glyphosate rate squared $(\mathrm{P}=0.03)$ :

$\operatorname{Ln}($ tomato dry weight $)=2.04-(6.47 \times$ glyphosate rate $)-(0.63 \times$ surfactant rate $)$ $+\left(9.88 \times\right.$ glyphosate rate $\left.^{2}\right)$

The best fitting model for the metsulfuron experiment included terms for metsulfuron rate $(\mathrm{P}=0.0004)$ and surfactant rate $(\mathrm{P}=0.02)$ :

$\operatorname{Ln}($ tomato dry weight $)=0.74-(1.02 \times$ metsulfuron rate $)-(0.3 \times$ surfactant rate $)$

TABLE 1: Treatments and average tomato dry weight production.

\begin{tabular}{|c|c|c|c|c|c|c|}
\hline \multirow[b]{2}{*}{ Treatment } & \multirow[b]{2}{*}{$\begin{array}{l}\text { Application } \\
\text { Volume } \\
\text { (litre/ha) }\end{array}$} & \multirow[b]{2}{*}{$\begin{array}{c}\text { Surfactant } \\
\text { (litre/ha) }\end{array}$} & \multicolumn{2}{|c|}{ Expt 1} & \multicolumn{2}{|c|}{ Expt 2} \\
\hline & & & $\begin{array}{l}\text { Glyphosate } \\
\text { (kg/ha) }\end{array}$ & $\begin{array}{l}\text { Average } \\
\text { dry wt } \\
(\mathrm{g})\end{array}$ & $\begin{array}{l}\text { Metsulfuron } \\
\text { (g/ha) }\end{array}$ & $\begin{array}{c}\text { Average } \\
\text { dry wt } \\
\text { (g) }\end{array}$ \\
\hline 1 & 50 & 0.5 & 0.180 & 1.95 & 0.30 & 1.33 \\
\hline 2 & 80 & 0.2 & 0.072 & 5.02 & 0.12 & 2.11 \\
\hline 5 & 80 & 0.2 & 0.288 & 2.78 & 0.48 & 1.43 \\
\hline 3 & 80 & 0.8 & 0.072 & 3.54 & 0.12 & 1.52 \\
\hline 4 & 80 & 0.8 & 0.288 & 1.62 & 0.48 & 1.08 \\
\hline 7 & 125 & 0.0 & 0.180 & 2.92 & 0.30 & 1.34 \\
\hline 6 & 125 & 0.5 & 0.180 & 2.41 & 0.30 & 1.36 \\
\hline 10 & 125 & 0.5 & 0.360 & 1.76 & 0.60 & 0.83 \\
\hline 8 & 125 & 0.5 & 0.000 & 8.93 & 0.00 & 2.88 \\
\hline 9 & 125 & 1.0 & 0.180 & 1.87 & 0.30 & 1.17 \\
\hline 13 & 170 & 0.2 & 0.288 & 2.64 & 0.36 & 1.31 \\
\hline 14 & 170 & 0.2 & 0.072 & 4.24 & 0.12 & 1.51 \\
\hline 12 & 170 & 0.8 & 0.288 & 1.58 & 0.36 & 0.99 \\
\hline 11 & 170 & 0.8 & 0.072 & 2.69 & 0.12 & 1.36 \\
\hline 15 & 200 & 0.5 & 0.180 & 2.53 & 0.30 & 1.43 \\
\hline
\end{tabular}

LSR(5\%), Expt. 1: 0.334 and 0.255 for edge points and centre point and any single edge points, Expt. 2: 0.257 and 0.196 for edge points and any single edge points. 
Figs. 1 and 2 show the predicted response surfaces for this relationship. No other interactions or quadratic terms were significant for either model. The models had $\mathrm{R}^{2} \mathrm{~s}$ of $89 \%$ and $75 \%$ with respect to the glyphosate and metsulfuron experiments. At rates used in either experiment, surfactant in the absence of herbicide, did not affect tomato dry weight production (Ray et al. 1996).

The results clearly show that above-ground tomato dry weight production, following treatment with sub-lethal rates of either glyphosate or metsulfuron, is sensitive to the per hectare rate of herbicide, and per hectare rate of surfactant but not to the per hectare application volume (over the range 50-200 litre/ha). Gaskin et al. (1996) showed that height growth of tomatoes, treated with a constant but sub-lethal rate of glyphosate, could be predicted $\left(\mathrm{P}<0.0002, \mathrm{R}^{2}=75 \%\right)$ by a linear model using total organosilicone dose (rate/ha) over a wider range of application volumes (50-400 litre/ha). Decreasing the percent concentration of organosilicone surfactant can decrease herbicide uptake (Stevens and Zabkiewicz 1990) and efficacy (Balneaves et al. 1993). Thus if the volume of added surfactant is expressed in terms of percentage $(\mathrm{v} / \mathrm{v} \%)$ rather than at a fixed rate per hectare, it can be envisaged that, as spray volume is decreased, a point may be reached when quantity of organosilicone is insufficient to enhance uptake. The effect could be exacerbated by either surfactant antagonism due to the agrochemicals formulants (Knoche and Bukovac 1993) or to leaf surface absorption (Buick et al. 1993). The current trial and previous studies (Gaskin et al. 1996; Ray et al. 1986; Vanner and Ray 1988) support to the hypothesis that, for foliage absorbed herbicides, efficacy is highly dependent on surfactant rate per hectare in both laboratory and field conditions. In the aerial spray trials, provided the rate/ha of surfactant was maintained at that recommended for a standard 200 litres/ha application, reducing the application volume to 50 - 20 litres/ha did not reduce herbicide efficacy.

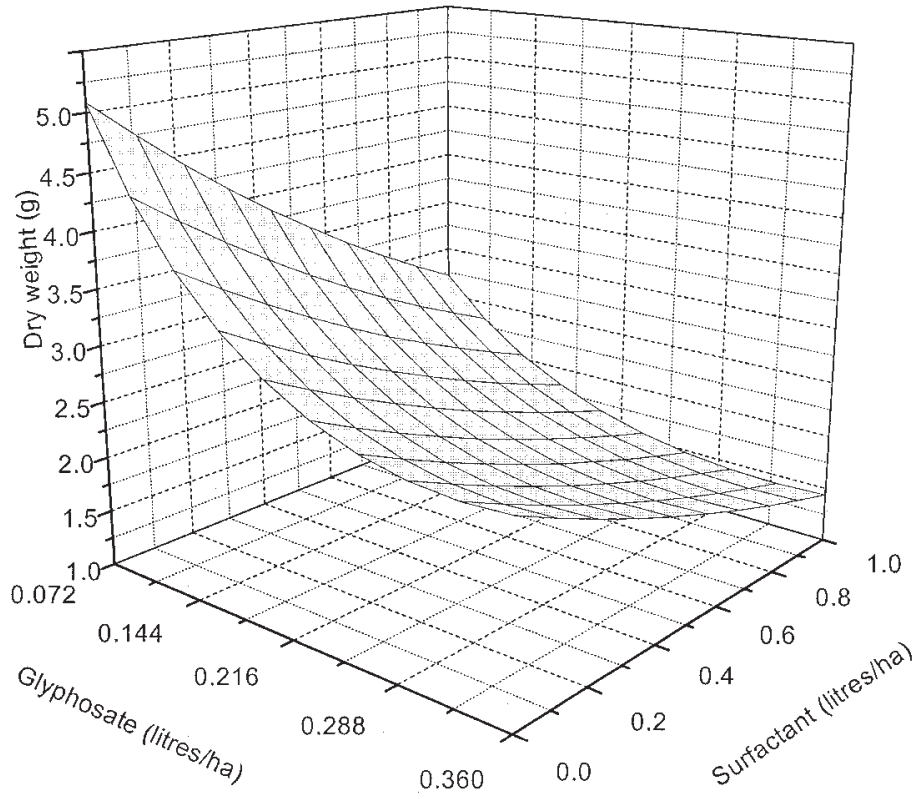

FIGURE 1: Predicted tomato dry weight production based on the per hectare rates (litres/hectare) of glyphosate and surfactant. 




FIGURE 2: Predicted tomato dry weight production based on per hectare rates (litres/hectare) of metsulfuron and surfactant.

\section{ACKNOWLEDGEMENTS}

The authors wish to thank Mark Kimberly for advice on experimental design and assistance with the statistical analysis.

\section{REFERENCES}

Balneaves, J.M., Gaskin, R.E. and Zabkiewicz, J.A., 1993. The effect of varying glyphosate rates of glyphosate and an organosilicone surfactant on the control of gorse. Annals. Appl. Biol. 122: 531-536.

Buick, R.D., Buchan, G.D. and Field, R.J., 1993. The role of surface tension of spreading droplets in absorption of a herbicide formulation via stomata. Pesticide Sci. 38: 227-235.

Cochran, W.G. and Cox, G.M., 1968. In: Experimental Designs, $2^{\text {nd }}$ Edition, Pub. John Wiley and Sons Inc.

Gaskin, R.E., Murray, R.J. and Ray, J.W., 1996. Interaction of organosilicone surfactant concentration and spray application factors in determining foliage herbicide efficacy. Proc. 49th N.Z. Plant Prot. Conf:: 183-187.

Knoche, M., 1994. Organosilicone surfactant performance in agricultural spray performance. A review. Weed Res. 34: 221-239.

Knoche, M. and Bukovac, M.J., 1993. Interaction of surfactant and leaf surface in glyphosate absorption. Weed Sci. 41: 87-93.

Ray, J.W., Vanner, A.L. and Richardson, B., 1986. Effect of application volume and spray additive concentration on the control of bracken. Proc. 39th N.Z. Plant Prot. Conf:: 89-91.

Ray, J.W., Vanner, A.L. and Richardson, B., 1991. Productivity of fixed- and rotorwinged aircraft for applying herbicide sprays. Pp 254-258. In: Proceedings of IUFRO Symposium on "Efficiency of Stand Establishment Operations". M.I. 
Menzies, G.E. Parrot, and L.J. Whitehouse (Eds), Ministry of Forestry, FRI Bulletin No. 156.

Ray, J.W., Vanner, A.L., Richardson, B. and Coker, G., 1996. Determination of the NOEL of four commonly used forestry herbicides on tomatoes. Proc. 49th N.Z. Plant Prot. Conf:: 188-191.

SAS Institute Inc. 1988. SAS/STAT User's Guide. SAS Institute Inc., Cary, NC, USA. Stevens, P.J.G., 1993. Organosilicone surfactants as adjuvants for agrichemicals. Pestic. Sci. 38: 103-122.

Stevens, P.J.G. and Zabkiewicz, J.A., 1990. New formulation technology- Silwet organosilicone surfactants have physical and physiological properties which enhance the properties of sprays. Proc. 9th Aust.Weed Conf.: 145-150.

Stevens, P.J.G., Gaskin, R.E., Hong, S.-O, and Zabkiewicz, J.A., 1991. Contributions of stomatal infiltration and cuticular penetration to enhancements of foliage uptake by surfactants. Pestic. Sci. 33: 371-382.

Vanner, A.L. and Ray, J.W., 1988. The effect of water volume on metsulfuron applied to gorse. Proc. 41st N.Z. Weed and Pest Cont. Conf: : 160-170. 